\title{
Degradation of Primate Habitat at Tesso Nilo Forest with Special Emphasis on Riau Pale-Thighed Surili (Presbytis siamensis
} cana)

\author{
Jatna Supriatna ${ }^{1,2}$, Sri Mariati2 \\ ${ }^{1}$ Department of Biology and Research Center for Climate Change, Universitas Indonesia, Depok, Indonesia \\ ${ }^{2}$ Graduate School on Environment, Universitas Indonesia, Jakarta, Indonesia \\ Email: jatna.supriatna@gmail.com
}

Received 9 July 2014; revised 4 August 2014; accepted 28 August 2014

Copyright (C) 2014 by authors and Scientific Research Publishing Inc.

This work is licensed under the Creative Commons Attribution International License (CC BY). http://creativecommons.org/licenses/by/4.0/

\section{(c) (i) Open Access}

\section{Abstract}

The habitat of Riau pale-thighed surili (Presbytis siamensis cana) located in Riau province of Sumatra island between Siak in the north and Indragiri rivers in the south, has been seriously degraded in the last a few decades. This swampy peat land forest has been degraded by frequent burning during the dry season. These problems originated because of poor governance on the forest management, and the construction of two access roads by the owners of logging concessions and wood pulp plantations. This forest block consists of Tesso Nilo National Park, Kerumutan protected area, Production Forest areas belong to two companies, and a small recreation Park. It also contains one of the most important mixed peat swamp forests. Here, we tracked changes in forest cover before and after road construction using GIS and remote sensing imagery. Deforestation rates have increased from $1.5 \%$ per year before road construction to $9.28 \%$ per year after road construction, which means that the area of forest has decreased by an annual average of 8156 ha in Tesso Nillo alone. The habitat of Riau pale-thighed surili decreased almost up to $60 \%$ in the last decade after companies started their converting forest for oil palm and acacia and roads were built crisscrossed. If the trend of deforestation continues, further decline of population of habitat of this species is unavoided. Researches should be carried out in more details to understand the status of population of this subspecies before this subspecies disappears in the wild.

\section{Keywords}

Deforestation, Primate Habitat, Tesso Nilo Forest, Presbytis siamensis cana, Sumatra, Indonesia 


\section{Introduction}

The habitat of many Sumatra primates has been in the state of danger recently [1]. Sumatra was still densely forested as recently as 1950, but then clearance began in 1970 when the lowland areas, where topography and soil fertility were most favorable to human settlement and agriculture. Clearance for plantation crops in the colonial era and for transmigration programs in the 1970s and 1980s also occurred largely in lowlands or on gently sloping foothills [2]. Commercial logging concentrated first on lowland forests, which were accessible, commercially valuable, and had the greatest potential for large-scale development [3]. Unfortunately, lowland forests are also the most biologically diverse, harboring many of the most prized tree and animal species in Sumatra [4].

Since the early 1970s, Sumatra Island has lost 6.6 million ha of forest or 557,000 ha per year due to legal and illegal logging, conversion of natural forests to industrial plantations, and forest encroachment by communities. Of this total, 2.6 million ha were natural tropical rain forest [5]. The largest area, about 30\% (about 5 million ha) was lost from Riau Province, with the next largest loss, 21.7\% (about 3.6 million), from Nanggroe Aceh Province. Riau province has approximately 8.6 million ha of forest remaining [6] but also the highest rate of loss, about 42\% between 1990 and 2010 [5]. Within Riau province, the Tesso Nilo Forest block is the largest block of forest remaining (377,387 ha) consisting mainly of lowland tropical rain forest, heat forest and peat swamp forest [7].

Those high deforestation rates in many places in Sumatra were not only in the logging concessions but also in the protected areas and national parks included in the Tesso Nillo park [8]. At Tesso Nilo National Park, 7 species of primates have been found and those are Siamangs (Hylobates syndactylus), Agile gibbon (Hylobates agilis), 2 species Macaques (Macaca fascicularis and Macaca nemestrina), Silvery leaf monkey (Trachypi-thecus cristatus ), Coucang (Nycticebus coucang) and Riau pale-thighed surili (Presbytis siamensis cana) [1] [9]. Palethighed surili (Presbytis siamensis) diversed into several species $P$. siamensis paenulata (Barimun river up to Northern Sumatra), P. siamensis siamensis (Malay penninsula), P. siamensis rhionis in Bintan and Batam island and $P$. siamensis cana in Kundur island and between Siak and Inderagiri rivers [10]-[12].

This Riau pale-thigh leaf monkey lives in the lowland of Central Eastern Sumatra included Tesso Nilo Forest, Kampar forest and Kerumutan protected area which harbors very high biodiversity. From $200 \mathrm{~m}^{2}$ samples, it was found 218 tree species in Tesso Nilo Forest, which is one of the richest diversity of plants in the world [13]. The lowland forest is also an important habitat for endangered species such as the Sumatran tiger (Panthera tigris sumatrae) and Sumatran elephant (Elephas maximus sumatraensis). However, as large areas of this habitat have been converted into oil palm and pulp wood plantations, and settlements, conflicts between humans and biodiversity protection have increased [5] [8].

In Tesso Nilo Forest, serious conflicts between production and the protection of biodiversity, ecosystem functions and cultural values began after the construction of two road corridors, Baserah and Ukui between 2000 and 2012. WWF and many other NGOs have been trying to quantify the forest and biodiversity loss from the crisscrossed roads that resulted from these two major road corridors. In this study we describe the rate of deforestation in the Tesso Nilo Forest by mapping the extent of deforestation, and by calculating the rate of deforestation post road construction that may impact to primate populations and propose some policies and actions to help mitigate this forest loss [14]. In our prvious studies [8], we discussed the deforestation of Tesso Nillo due to the roads built across the park and impact to the population of elephants, and here in this paper we are estimating the impact of deforestation on the primates in Tesso Nilo Forest especially toward the locally endemic subspecies which is Riau Pale-thighed surili, Presbytis siamensis cana.

\section{Methods}

\subsection{Study Area}

The Tesso Nilo Forest (formerly Langgam Forest) covers an area of 377,387 ha and is located in the Pelalawan, Kuantan Singingi, Kampar and Indragiri Hulu Districts, in the province of Riau in the central part of Sumatra (ca. $102^{\circ} \mathrm{E}$ and equator). The forest block is surrounded by Acacia plantations (80\%), oil palm estates (13\%) and village gardens (5\%) [8]. This forest is about 3 hours drive south of Pekanbaru, the capital of Riau Province. Riau is one of the richest provinces in Indonesia, yet more than $40 \%$ of the population lives below the poverty line [8].

Tesso Nilo harbors humid tropical lowland forests and some peat swamp forests and its altitude ranges from 0 
to 125 meters above sea level. With annual rainfall of 2000 - $3000 \mathrm{~mm}$, it is classified as super humid. During El Niño climatic episodes, however, many trees may be defoliated and some eventually die. Episodic droughts of this kind facilitate forest removal by human-induced fire, as has been the case in recent years [8].

The roads crisscrossing the Tesso Nilo Forest were built by the pulp and paper industry because their plantations are located on both the western and eastern sides of the forest block. In 2002-2004, the Baserah road, 50 $\mathrm{km}$ long, was built north to south with an average width of approximately $20-25 \mathrm{~m}$, while Ukui road, $30 \mathrm{~km}$ long, was built from west to east also with an average width of 20 - 25 in 2004-2006 (Figure 1).

\subsection{Land Use Change}

Landsat image interpretation and overlay and calculation of the average deforestation rate using formula that has previously used [15]. Percentage calculations of deforestation of the concession area and National Park were made using the Ministry of Forestry formula [16]. The method used to predict the pattern of trends in deforestation to 2018 was the Idrisi software tool Land change modeler. We are using a Land Use and Land Use Change Cover on the analog format at the scale of 1:250,000 from 2000-2012. This source originally came from Satellite images and then was validated using Google map and ESRI online base map. Deforestation was calculated based on:

a) Calculation was carried out on the condition when forest cover is still intact at the year 2000 and hereafter every 2 years up to 2012.

b) Landsat images should be free from the cloud.

c) All images from parks, forest companies and protected forests were analyzed.

\subsection{Primate Habitat Analysis}

Primate survey had been carried out by many researchers included our brief surveyed around Tesso Nillo forest area and toward Indragiri hilir basin. [9] surveyed biodiversity of Tesso Nillo Forest found at least 6 primates, those are the most common up to the rare in Sumatra Long tail macaque (Macaca fascicularis), Pig tail macaques (Macaca nemestrina), Silvery leaf monkey (Trachypithecus cristatus), Coucang (Nycticebus coucang), Siamang (Symphalangus syndactylus) and Agile gibbon (Hylobates agilis). However, they failed to find one very important species that found endemic into this area between Siak and Indragiri rivers, Riau pale-thigh leaf monkey (Presbytis siamensis cana) which was found in the area mostly close to coastal area (Figure 1 and Figure 2). This species very limited distribution around the Tesso Nillo forest, which has been categorized in IUCN Redlist category as NE (not evaluated) [1] [11] [12] [17]. It is the only subspecies primates that lives in around Tesso Nillo Forest, Kerumutan, Kampar peninsula, and small forest block surounding Kundur island. Based on current data of distribution, we checked several locations in the forested area, and also from information gathering in the primate distribution, we calculated deforestation rate in their habitat only in the Tesso Nilo Forest.

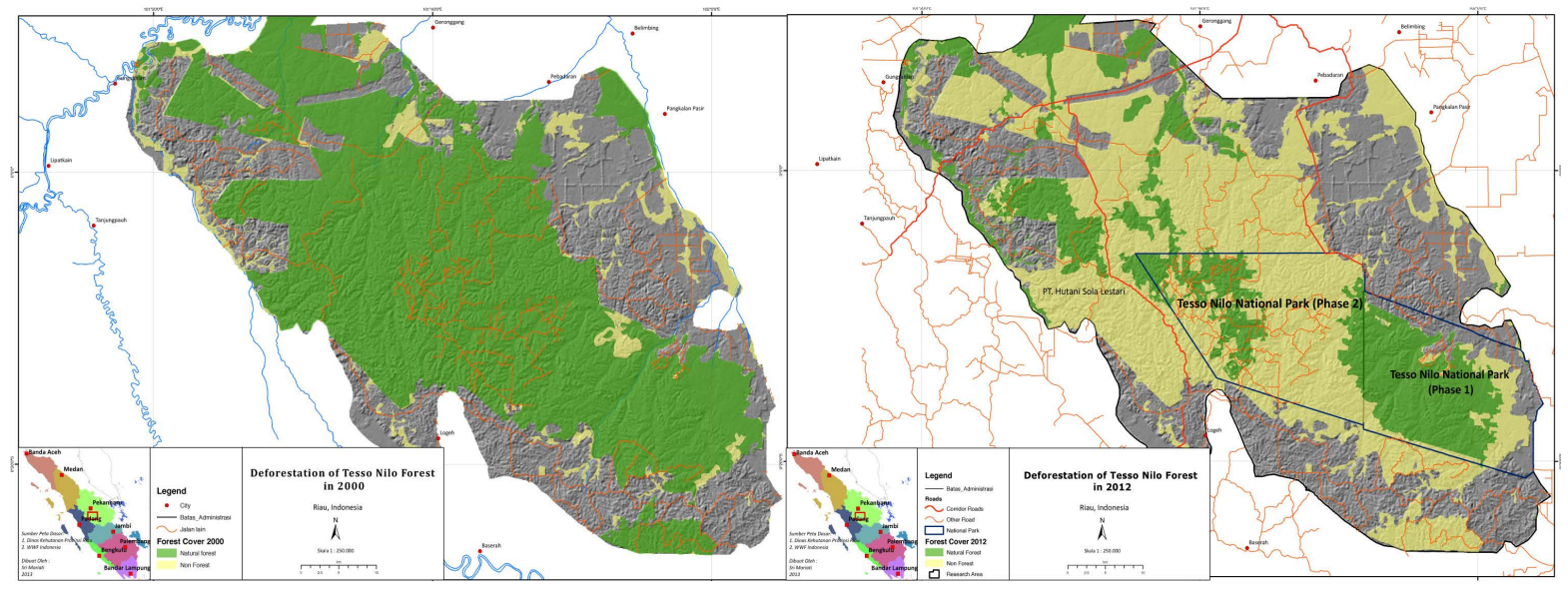

Figure 1. Deforestation of Tesso Nilo Forest in 2000 (left) and 2012 (right), boundary of logging companies (HPH) and national park (phase 1 and Phase 2), and new roads built ( Baserah and Ukui Roads). 


\section{DEFORESTATION IN LOGGING CONCESSIONS AND NATIONAL PARK 2000-2012}

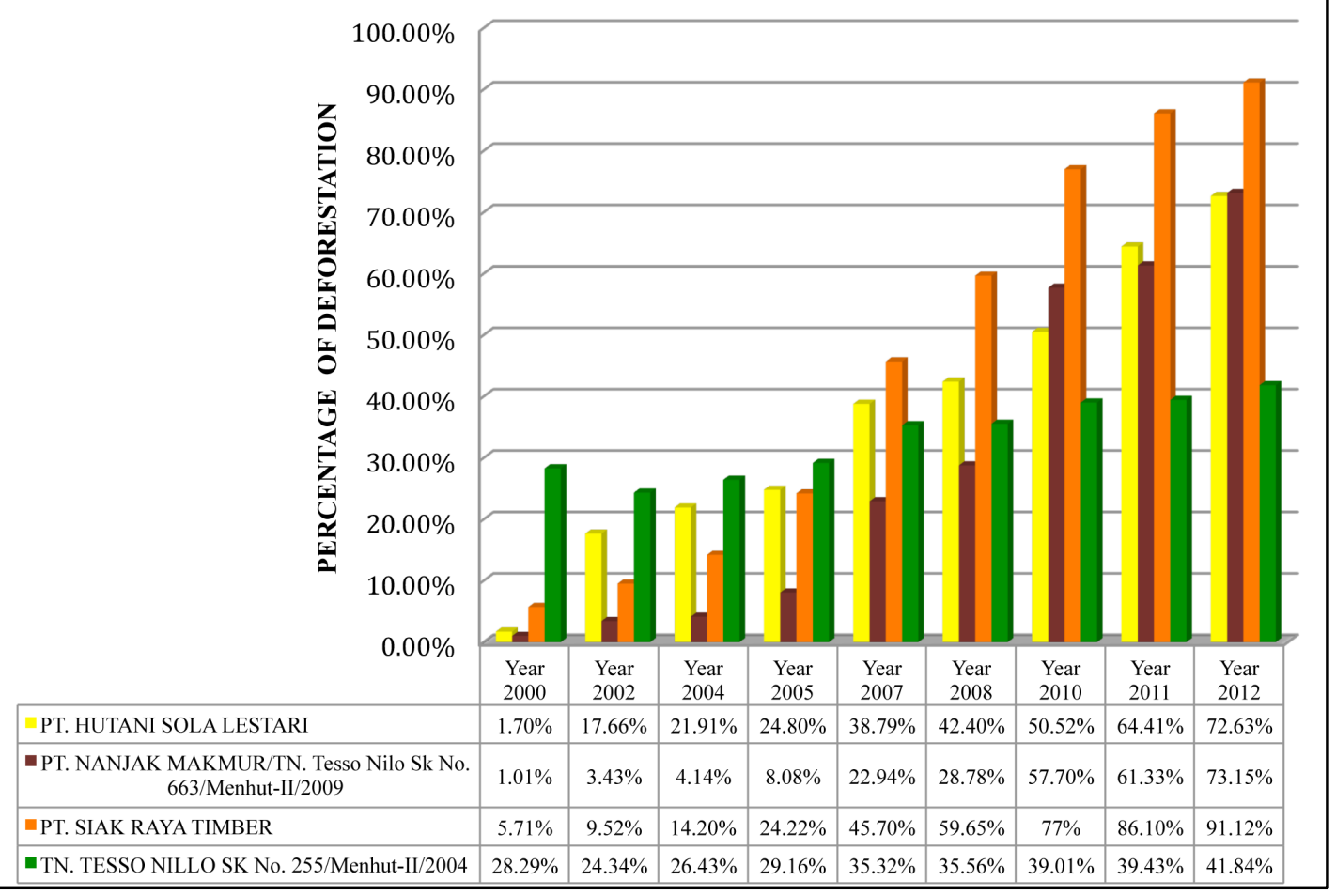

Figure 2. Graphs of deforestation of company concessions and national park from 2000-2012.

\section{Results and Discussion}

Between 1990 and 2002, Tesso Nilo lost forest area to legal and illegal logging, settlements, oil palm and pulp wood plantations and other forms of agriculture. At that stage, deforestation was concentrated mostly in the logging concessions. However, from our previous research [8] the rate of deforestation increased significantly when access to the middle of the forest block was opened up by construction of Baserah and Ukui roads. Between 2000 and 2012, the area of forest decreased by 8156.97 ha, which represents a deforestation rate of $9.28 \%$ per year. If we break this down further the average rate of deforestation between 2000 and 2002 was $2.40 \%$ per year between 2002 and 2004 it was 4.06\% per year (after Baserah road was completed and construction of Ukui road was commenced) and the average rate of deforestation after Baserah and Ukui roads were both completed, between 2005 and 2012, was 13.88\% per year. Clearly, these two roads are important factors in deforestation (Figure 2).

Based on model projections of trends in deforestation from 2000 to 2012, in 2018, only approximately 28,017 ha of the Tesso Nilo Forest will remain (Figure 1). These projected results reveal the importance of incorporating spatial patterns into the planning process dealing with settlement and forest encroachment. For example, if a pattern indicates a high risk of deforestation due to road access, then the government plan should mandate no clearing for access roads without strict control and tight security. It is clear that the two road corridors have facilitated encroachment and forest conversion. Figure 2 showed that the deforested area in PT Hutani Sola Lestari increased significantly from $1.70 \%$ (2000) to $17.66 \%$ (2002) after the Baserah road was built. After both roads were built the deforestation rate in this concession between 2000 and 2012 was 72.63\% (Figure 2).

At the Nanjak Makmur logging concession, the average deforestation rate to the year 2000 was $1.01 \%$, which was lower than any other company. The rate had increased to $3.43 \%$ by 2002 . However, it then jumped significantly from 2005 onwards as the roads were completed or in progress so that by 2012, 73.15\% of the Nanjak Makmur concession was deforested. This was happening even when the whole forest of Nanjak Makmur logging concession was converted into Tesso Nilo National Park (phase 2) in 2009, based on Ministerial Decree (663/Menhut-II/2009). 
At the Siak Raya concession, the deforestation rate to 2000 was $5.71 \%$. By 2002 it had nearly doubled to $9.25 \%$. This trend increased significantly and by 2012 up to $91.12 \%$ of the forest was lost. In comparison to other companies, the overall deforestation rate in the Siak Raya concession is the highest, at $19.69 \%$ over 12 years. The reverse of this trend is evident in the Tesso Nilo National Park phase 1. This area was logged over forest but recovered and was reforested at a rate of $2.69 \%$ per year from 2000 to 2002 and $1.28 \%$ per year from 2002 to 2004 before it was declared national park. The overall deforestation rate in the park, including from 2000-2004 when it was a recovering logging concession, was only $1.74 \%$ for a total deforested area in 2012 of $41.84 \%$ (Figure 2).

Roads that were built by pulp and paper companies to transport timber from logging concessions to mills have also provided access for both illegal loggers and people seeking land for settlement. In addition, existing communities around the forest have used the roads to gain access to new small areas deep within the forest. From our satelite map analysis, the pattern of deforestation looks like a honeycomb, where road serve as an axis while people access from the road across the miles along the forest, a pattern that has been found in many other tropical countries. The accessibility of forest areas is the most important variable in the pattern of the deforestation [18]. In general, the cause of deforestation is the land use change due to the conversion of the forested land for agriculture, plantation and timber activities [19] but the enabling factor is road construction [20].

Illegal logging in the Tesso Nilo National park (phase 2) is increasing in conservation areas, since these areas have better timber potential than production areas (Figure 1). We agree with the Ministry of Forestry conclusion in 2000 that the main actors in illegal logging are: a) laborers from communities in the forest areas and also many who are brought there from other areas; b) Investors, including traders, concession holders, or holders of legal timber cutting permits (IPK), and buyers of illegal timber from processing industries; and c) government officials (both civilian and military), law enforcement personnel, and certain legislators. The Ministry of Forestry has officially stated that Illegal logging has come to constitute a well-organized criminal enterprise with strong backing and a network that is so extensive, well-established and strong that it is bold enough to resist, threaten, and in fact physically tyrannize forestry law enforcement authorities. Illegal cutting occurs in concession areas, unallocated forest areas, expired concessions, state forestry concessions, areas of forest slated for conversion, and in conservation areas and protected forests [21].

Even though logging concessions are intended to maintain forest lands in permanent production, the concession system has, in fact, been a major cause of deforestation and forest degradation in non-concession areas such as national park, forest protection and other forest belong to customary community [22]. The Directorate-General Forest Protection of Nature Conservation (PHKA) in the Ministry of Forestry is responsible for managing protected areas and national parks for preparing and implementing regulations in accordance with legislation that went into force in 1990. Even with decentralization of management to the district level, the PHKA retains responsibility for management of terrestrial protected areas and parks. Management of other forest areas-including watershed and protection forests, production forests, and local protected areas of limited conservation value, such as recreational parks are devolved to the district level. At the same time, local governments must now supplement block grants by raising revenue within their kabupatens, or districts. This creates tension between local governments and conservation officials, as protected areas and parks occupy land on which no land tax is collected. Eco-tourism in national parks has not contributed sufficient revenue to offset this loss in taxes. Most Indonesian NGOs expect that conservation outcomes will be determined by district managers and district parliaments, regardless of national government policies [5].

Changing production forest into national park such as Tesso Nilo by converting the tenure of logged-over areas seems to be a secure and effective way of reducing deforestation, based on our findings. However, even though some forest in this block has been proposed for conversion to national park status, due to the slow and confusing process of demarcating forest boundaries (phase 2 of Tesso Nilo National Park), there are overlapping and conflicting claims to lands within the park and with other forested land belong to companies. This legal uncertainty makes it easier to excise land from the proposed park for other uses irregular and inadequate financing for ongoing administrative costs for park development at Tesso Nilo also limits the effectiveness of the national park. As found throughout Sumatra protected areas and national parks are poorly funded and equipped, and some receive no regular budgets at all. Priority areas rely on supplementary donor funding, which covers only a limited project period. In several national parks supported by international donors, annual forest loss is similar to that in under-funded areas [5] [22]. 


\section{Implications for Primate Conservation}

As human populations increase and more and more forest is converted to estates and agricultural lands, wildlife-human conflicts are on the rise. Until recently, that appeared to be Tesso Nilo's future as well. Since 1985, the forest has lost over 300,000 ha to the oil palm and pulp and paper industry, so that only about 190,000 ha main today [8] [23]. Primates especially macaques, leaf monkeys and surili have been known to raide the crops such as leaves of oil palm and acacia of the industrial estates plus agriculture commodities such as corns, vegetable and perenial plants belong to small holders. Therefore capturing monkeys, poisoning and killing them were reported everywhere from interviewed in Tesso Nilo area. Scaterred populations of those primates except gibbons found in the close vicinity of old villages where most of them living in the small pocket forests. In the big estates of oil palm and acacia, we did not found any of those primates.

Siamang and agile gibbons found in Sumatra will confine their teriritory instead of expanding their daily ranges in the disturbed and fragmented forest. It was found that their home ranges did not correlate with fragment size but with presence of neighbouring group and food availability. In oil palm and acacia plantation, the food was not available and in the secondary and logged over forest. The reduction of food available was also significant [24].

From calculating the current primate habitat, it seems that most of those primates may not survive either in the oil palm and acacia plantations. Leaf monkeys, surili and macaques may survive in the logged over area as we had checked in the field but not for siamangs and agile gibbons. These two gibbon species have been spotted in the good forest only and some in the good logged over area in Tesso Nilo Forest especially at the national park. However, those gibbon distribution ranges in Sumatra are wide almost across Sumatra for siamang and more than half of the island for agile gibbon [17]. Both macaques distribution are also very wide into Sumatra and Kalimantan, similar to silvery leaf monkey (Trachypithecus cristatus) and coucang (Nycticebus coucang). Therefore, the only vulnerable of those above primates is only the subspecies of Riau Pale-thighed surili (Presbytis siamensis cana). After overlaying the distribution of this subspecies and the current forest left, it seems that this subspecies lost already significant (almost 60\%) of their habitat. The only good forest left are on the Tesso Nilo national park (phase 1) and also and in some of Kerumutan protected area and Kampar Forest block. Our brief survey of this species in Tesso Nilo Forest resulted that they found in the small gallery forest along the rivers and also in community rubber plantations.

Researches on this subspecies of surili have not carried out in the field until now. There have been some confussion on the species name and many previous studies had been using P. melalophos or P. femoralis [11]. But currently it has been categorized into P. siamensis cana [10]. For example, many researches on the Pale-thighed surili have used P. femoralis in Malaysia and Singapore. Our understanding of the ecology of this subspecies was very little but for other subspecies such as P. siamensis has been carried out in Malaysia. In Malaysia, this species lives in primary rainforests and can tolerate logged forests [25] and also rubber plantations [26]. In Sumatra, this species lives in mixed mangrove, primary freshwater, riverbank, primary lowland logged, scrubgrassland riverbank, and secondary riverbank forests [27].

The Pale-thigh surili is primarily a frugivorous species that also consumes immature leaves. The seeds are the part of the fruit most consumed, at Kuala Lompat, Malaysia. The diet of this species was found to be composed of $42.8 \%$ fruit, $42.6 \%$ leaves, and $14.6 \%$ flowers [28]. In West Sumatra, this species was found to feed on the leaves of the rubber species of Hevea brasiliensis and Ficus variegata [29]. Although this species is primarily an arboreal species, the surili has been found to come to the ground to forage for the fruits of the species Castanopsis megacarpa and Garcinia parvifolia [30]. At Kuala Lompat Malaysia, it was found that the diet of the surili was composed of $48 \%$ fruit, $24 \%$ new leaves, $11 \%$ mature leaves, $8 \%$ seeds and beans, $6 \%$ flowers, and $2 \%$ others [26]. From those above diet and habitat information of other species, it seems that Riau pale-thigh surili presumably can adapt in the plantations and logged over forest. Our observation in the field showed that this surili can survive in the old villages, rubber plantation and pocket forest and of course in the logged over forest and primary forest, but we had never found tehm at the oil palm and acacia plantations.

\section{Conclusions}

Serious deforestation has been happening in the Tesso Nilo Forest block in Riau Province, Indonesia. This deforestation was found really high in the production forest and even at the Tesso Nilo National Park. The encroachers came to convert the forest with primary purpose to grow oil palm and get access into the forest after 
crisscrossing two roads built connecting several big plantations around Tesso Nilo Forest. Those two roads were built in 2002 and 2004 crossed in the middle of the forest block, and very close to the national park, as a result, not only in the production forest deforested heavily but also in the national park.

This high deforestation impacted the habitat of many primates living in the Tesso Nilo Forest. Habitat siamangs and gibbon have been decreased sharply. Since their distribution ranges in Sumatra are very wide, their overall populations may not decline sharply. However, the endemic leaf monkey in the Tesso Nilo Forest will be really significant reduced, and if this trend continues, the Riau Pale Thighed Surili (Presbyts siamensis cana) may not be seen at Tesso Nilo Forest, or the population will reduce sharply.

\section{Acknowledgements}

We thank to our colleagues who help in training, formulating and letting the GIS equipment which was used, especially Weda and Samsuardi from WWF Indonesia, Hendi Sumantri from Conservation International, Chris Margules from James Cook University, Grace Wong from CIFOR, our colleagues at the University of Indonesia's Post Graduate Study on Environment and Biology Department and many other people in Tesso Nilo and Riau provinces that we cannot put their names due to the limited space.

\section{References}

[1] Supriatna, J., Manansang, J., Tumbelaka, L., Andayani,N., Indrawam, M., Darmawan, L., Leksono, S.M. and Djuwantoko, B.O. (2001) Conservation Assessment and Management Plan for the Primates of Indonesia: Final Report. IUCN/SSC Conservation Breeding Specialist Group, Apple Valley.

[2] Whitten, A.J., Damanik, S.J., Anwar, J. and Hisyam, N. (1987) Ekologi Sumatra. Gadjah Mada University Press, Jogjakarta.

[3] Sunderlind, W.D. and Resosudarmo, I.A.P. (1996) Rates and Causes of Deforestation in Indonesia: Towards a Resolution of the Ambiguities. CIFOR, Bogor.

[4] Supriatna, J., Wijayanto, I., Manullang, B.O., Anggraeni, D. and Wiratno, E.S. (2002) The State of Siege for Sumatra's Forest and Protected Areas: Stakeholders View during Devolution, and Political plus Economic Crises in Indonesia. Proceeding of IUCN/WCPA-East Asia, Taipei, 18-23 March 2002, 439-456.

[5] Margono, B.A., Turubanova, S., Zhuravieva, S., Potapov, P., Tyukavina, A., Baccini, A., Goetz, S. and Hansen, M.C. (2012) Mapping and Monitoring Deforestation and Forest Degradation in Sumatra (Indonesia) Using landsat Time Series Data Sets 1990 to 2010. Environmental Research Letters, 7, Article ID: 034010.

[6] Pemerintah Provinsi Riau (2010) Riau Dalam Angka Tahun 2010, Pekanbaru. http://riau.bps.go.id/publikasi-online/\%5Bbook-raw\%5D/riau-dalam-angka-2010.html

[7] Mariati, S. (2004) Analisis Kebijakan Pengelolan Hutan Studi Kasus di Hutan Tesso Nilo Kabupaten Pelalawan Provinsi Riau, Padang.

[8] Mariati, S., Kusnoputranto, K., Supriatna, J. and Koestoer, R.H. (2014) Habitat Loss of Sumatran Elephants (Elephas maximus sumatranus) in Tesso Nilo Forest, Riau, Indonesia. Australian Jounal of Basic and Applied Science, 8, 248255.

[9] Lembaga Ilmu Pengetahuan Indonesia and WWF Indonesia (2003) Laporan Penelitian Keanekaragaman Hayati Hutan Tesso Nilo. Pekanbaru-Riau.

[10] Brandon-Jones, D., Eudey, A.A., Geissmann, T., Groves, C.P., Melnick, D.M., Morales, J.C., Shekelle, M. and Stewart, C.B. (2004) Asian Primate Classification. International Journal of Primatology, 25, 97-164. http://dx.doi.org/10.1023/B:IJOP.0000014647.18720.32

[11] Groves, C.P. (2001) Primate Taxonomy. Smithsonian Institution Press, Washington DC.

[12] Roos, C., Boonratana, R., Supriatna, J., Fellowes, J.R., Groves, C., Nash, S.D., Rylands, A.B. and Mittermeier, R. (2014) An Updated Taxonomy and Conservation Status Review of Asia Primates. Asian Primates Journal, 4, 2-38.

[13] Gillision, A.N. (2001) Vegetation Survey and Habitat Assesment of the Tesso Nilo Forest Complex. Unpublished Paper.

[14] World Wide Fund for Nature (2009) Konflik Gajah dan Manusia di Provinsi Riau. Pekanbaru. (Tidak Dipublikasikan).

[15] Puyravaud, J.P. (2003) Standardizing the Calculation of the Annual Rate of Deforestation. Forest Ecology and Management, 177, 593-596. http://dx.doi.org/10.1016/S0378-1127(02)00335-3

[16] Departemen Kehutanan (2008) Perhitungan deforestasi Indonesia tahun 2008. Pusat Inventarisasi dan Perpetaan Hutan. Badan Planologi Kehutanan, Jakarta. 
[17] Supriatna, J. and Hendras, E. (2001) Panduan Primata Indonesia. Yayasan Obor, Jakarta.

[18] Etter, A., Mcalpine, C., Wilson, K., Phinn, S. and Possingham, H. (2006) Regional Patterns of Agricultural Land Use and Deforestation in Colombia. Agriculture, Ecosystems \& Environment, 114, 369-386. http://dx.doi.org/10.1016/j.agee.2005.11.013

[19] Geist, H. and Lambin, E. (2001) What Drives Tropical Deforestation? A Meta-Analysis of Proximate and Underlying Causes of Deforestation Based on Subnational Case Study Evidence. LUCC Report Series 4, CIACO, Lou-vain-laNeuve, Belgium.

[20] Forest Watch Indonesia (2001) Expert Review Workshop “The State of the Indonesian Forest” Report. Bogor, 29-30 June 2001, FWI.

[21] Ministry of Forestry (2002) Statistik Kehutanan Indonesia. Jakarta.

[22] Supriatna, J. (2009) Melestarikan Alam Indonesia (Conserving Indonesia’s Nature). Yayasan Obor Indonesia, Jakarta.

[23] Uryu, Y., Mott, C., Foead, N., Yulianto, K., Budiman, A., Setiabudi, Takakai, F., Nursamsu, Sunarto, Purastuti, E., Fadhli, N., Hutajulu, C.M.B., Janicke, J., Hatano, R., Siegert, F. and Stuwe, M. (2007) Deforestation, Forest Degradation, Biodiversity Loss and $\mathrm{CO}_{2}$ Emission in Riau, Sumatra, Indonesia: One Indonesian Province's Forest and Peat Soil Carbon Loss over a Quarter Century and Its Plans for the Future. WWF Indonesia Technical Report, Jakarta.

[24] Yanuar, A. and Chivers, D. (2010) Impact of Forest Fragmentation on Ranging ad Home Range of Siamang (Sympahalangus syndactylus) and Agile Gibbons (Hylobates agilis). In: Gursky-Doyen, S. and Supriatna, J., Eds., Indonesia Primates, Springer, New York, 97-120.

[25] Bennett, E.L. (1986) Environmental Correlates of Ranging Behaviour in the Banded Langur. Presbytis melalophos. Folia Primatologica, 47, 26-38.

[26] Miura, S., Yasuda, M. and Ratnam, L.C. (1997) Who Steals the Fruits? Monitoring Frugivory of Mammals in a Tropical Rain Forest. Malayan Nature Journal, 50, 183-193.

[27] Curtin, S.H. (1976) Niche Separation in Sympatric Malaysian Leaf-Monkeys (Presbytis obscura and Presbytis melalophos). Yearbook of Physical Anthropology, 20, 421-439.

[28] Crockett, C. and Wilson, W.L. (1980) Survey of Sumatran Primates: Diversity and Abundance in a Shrinking Paradise. Tigerpaper, 8, 1-5.

[29] MacKinnon, J.R. and MacKinnon, K.S. (1980) Niche Differentiation in a Primate Community. In: Chivers, D.J., Ed., Malayan Forest Primates: Ten Years' Study in Tropical Rain Forest, Plenum Press, New York, 167-190. http://dx.doi.org/10.1007/978-1-4757-0878-3 6

[30] Mukhtar, A.S., Nazif, M. and Setiawati, T. (1990) Habitat and Behaviour of Red Lutung (Presbytis melalophos) in Bukit Sebelah Protection Forest, West Sumatra. Buletin Penelitian Hutan, 528, 1-12. 
Scientific Research Publishing (SCIRP) is one of the largest Open Access journal publishers. It is currently publishing more than 200 open access, online, peer-reviewed journals covering a wide range of academic disciplines. SCIRP serves the worldwide academic communities and contributes to the progress and application of science with its publication.

Other selected journals from SCIRP are listed as below. Submit your manuscript to us via either submit@scirp.org or Online Submission Portal.
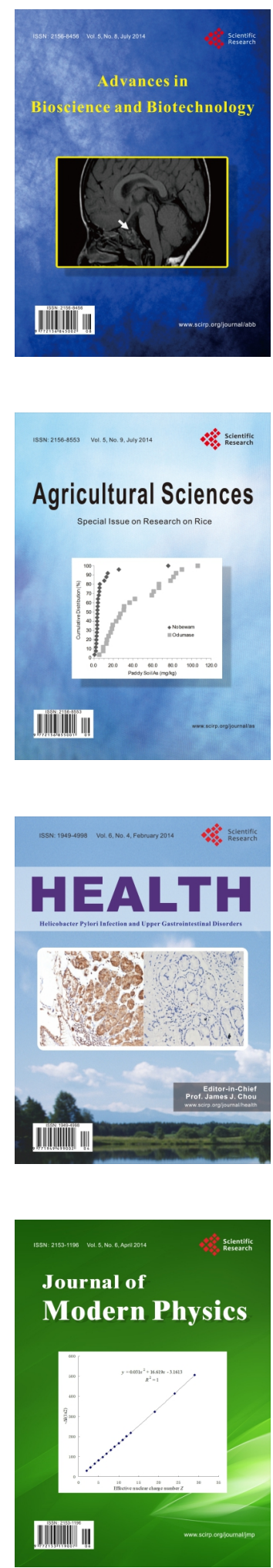
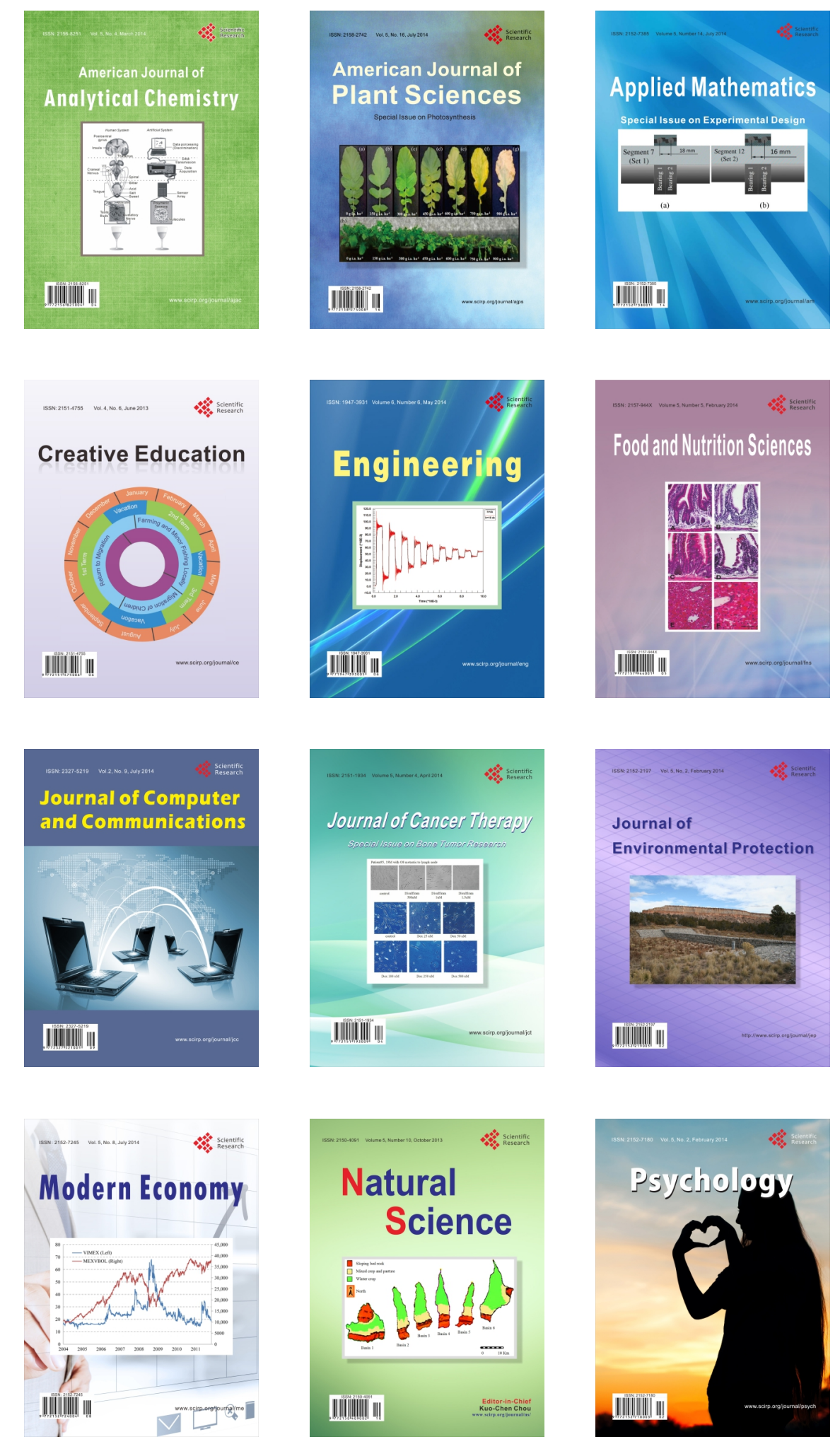